\title{
Volume Loss as a Tool to Assess Kiln Drying of Eucalyptus Wood
}

\author{
Djeison Cesar Batista ${ }^{1}$, Ricardo Jorge Klitzke ${ }^{2}$, \\ Márcio Pereira da Rocha ${ }^{2}$, Graciela Inez Bolzon de Muñiz ${ }^{2}$, \\ Tharcia Ribeiro Batista ${ }^{1}$
}

${ }^{1}$ Departamento de Ciências Florestais e da Madeira, Universidade Federal do Espírito Santo - UFES, Jerônimo Monteiro/ES, Brasil

${ }^{2}$ Departamento de Engenharia e Tecnologia Florestal, Universidade Federal do Paraná - UFPR, Curitiba/PR, Brasil

\begin{abstract}
In this study, we aimed to analyze the kiln drying quality of Eucalyptus grandis, Eucalyptus saligna and Eucalyptus dunnii woods with respect to volume loss. Wood from the three species was kiln dried together with the same drying schedule and conditions in a conventionaltemperature pilot kiln. Three kinds of volume loss were evaluated: total - from saturated (initial) to machined (final) condition; shrinkage - from saturated to $10 \%$ moisture content; and machining - from $10 \%$ moisture content to machined condition. Eucalyptus grandis wood was the most dimensionally stable and presented the smallest volume loss due to shrinkage. Although they had different shrinkage behaviors, Eucalyptus grandis and Eucalyptus saligna woods presented the same drying quality regarding machining and total volume losses. These species can be considered the same for kiln drying. Eucalyptus dunnii wood presented the worst quality in drying, and should not be kiln dried in the same batch with the other species.
\end{abstract}

Keywords: drying quality, species grouping, shrinkage and machining, Eucalyptus spp.

\section{Perda de Volume como Ferramenta para Avaliação da Secagem da Madeira de Eucalipto}

\section{RESUMO}

O objetivo deste trabalho foi avaliar a qualidade da secagem da madeira de Eucalyptus grandis, Eucalyptus saligna e Eucalyptus dunnii, em termos de perda de volume. A madeira das três espécies foi seca conjuntamente, com o mesmo programa de secagem e condições ambientais, em uma câmara-piloto de secagem convencional. Foram avaliados três tipos de perda de volume: total - da condição saturada (inicial) até a aplainada (final); contração - da condição saturada até $10 \%$ de umidade; usinagem - da condição saturada até a aplainada. A madeira de Eucalyptus grandis foi a mais estável dimensionalmente e apresentou a menor perda de volume na contração. Embora tenham comportamentos diferentes de estabilidade dimensional, as madeiras de Eucalyptus grandis e Eucalyptus saligna apresentaram a mesma qualidade de secagem, levando-se em consideração as perdas de volume no aplainamento e total. Estas espécies podem ser consideradas a mesma para a secagem convencional. A madeira de Eucalyptus dunnii apresentou a pior qualidade de secagem e não deve ser seca na mesma carga que as demais.

Palavras-chave: qualidade da secagem, agrupamento de species, contração e aplainamento, Eucalyptus spp. 


\section{INTRODUCTION}

Drying fast-grown plantation eucalypt wood is a very common practice in Brazil. Wood can be naturally pre-dried or not before kiln drying depending on the company. In both cases, conventional-temperature kiln drying is the most common practice among the artificial drying methods used in Brazil.

According to Simpson (1991), conventionaltemperature kilns typically operate in temperatures ranging from 40 to $80^{\circ} \mathrm{C}$. The majority of hardwood lumber and sizeable amounts of softwood lumber are dried to final moisture content in kilns operating within this temperature range. These include steamheated kilns and dehumidification kilns designed to operate up to $70{ }^{\circ} \mathrm{C}$. The bulk of the kiln schedules available for the various species and thicknesses are for kilns operating at conventional temperature.

Eucalyptus wood from fast-grown plantations is widely known as a difficult material to dry. This is because of its high growth stresses, low permeability (small cell dimensions and presence of tylosis) and most importantly the use of dimensionally instable and low-resistance juvenile wood, which lead to a wide variety of drying defects, from minor surface cracks to severe collapse.

Wood is dimensionally stable when the moisture content is greater than the fiber saturation point (FSP). Below the FSP, wood changes dimension as it gains (swells) or loses moisture (shrinks), because cell wall volume depends on the amount of bound water (Glass \& Zelinka, 2010).

Most defects that develop in wood products during drying can be classified as fracture or distortion, warp, or discoloration. Wood shrinkage is mainly responsible for wood ruptures and distortion of shape (Bergman, 2010).

Shrinking and swelling can result in warping, cracking, and splitting, which in turn can lead to decreased utility of wood products, such as loosening of tool handles, gaps in flooring, or other performance problems (Glass \& Zelinka, 2010).

Batista et al. (2010) studied the physical properties of the same material as in this study. Eucalyptus grandis and Eucalyptus saligna presented no statistically significant differences regarding density, 0.45 g. $\mathrm{cm}^{-3}$ and $0.46 \mathrm{~g} . \mathrm{cm}^{-3}$, respectively; while Eucalyptus dunnii presented the highest density, $0.56 \mathrm{~g} . \mathrm{cm}^{-3}$. They also studied the total (from saturated to oven dried) volumetric shrinkage of these species and obtained the following means: $14.10 \%, 15.16 \%$ and $18.71 \%$, respectively for Eucalyptus grandis, Eucalyptus saligna and Eucalyptus dunnii. All means were statistically different from each other, and the species were considered highly dimensionally unstable.

Warp in lumber is any deviation of the face or edge of a board from flatness or any edge that is not at right angle to the adjacent face or edge (squares). It can cause significant volume and grade loss. The five major types of warp are cup, bow, crook, twist and diamonding (Simpson, 1991). Flatsawn boards cup, as shown in Figure 1. Cupping results in slightly straighten growth rings (Langrish \& Walker, 2006).

Cupping occurs when shrinkage is greater in parallel than across growth rings. In general, the greater the difference between tangential and radial shrinkage, the greater the cupping degree. This defect can cause excessive loss of lumber in machining (Simpson, 1991).

Collapse is a distortion, flattening, or crushing of wood cells that occurs early in drying. In severe cases, collapse appears as grooves or corrugations, a washboard effect, at thin places in the board, as shown in Figure 2. Collapse may be caused by

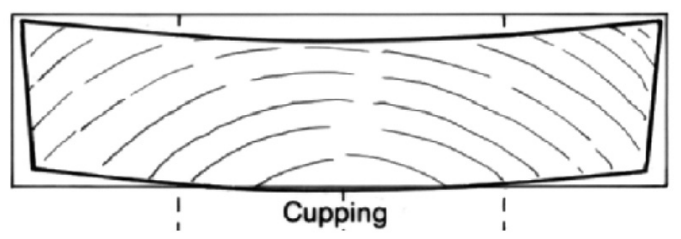

Figure 1. Cupping of a flatsawn board (Langrish \&Walker, 2006).

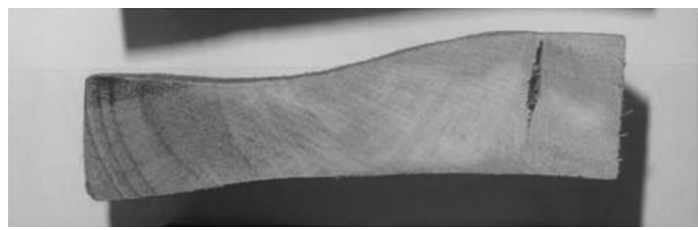

Figure 2. Cross section of a intermediary board of Eucalyptus dunnii presenting collapse, cupping and internal cracking. 
compressive drying stresses in the interior part of boards that exceed wood compressive strength, or liquid tension in cell cavities that are completely filled with water (Simpson, 1991).

Klitzke \& Batista (2010) studied the scoring of defects of small pieces oven dried at $100{ }^{\circ} \mathrm{C}$ of the same material as in this study. They predicted that Eucalyptus dunnii, when kiln dried, would present the worst quality. On the other hand, Eucalyptus grandis would have the best quality, followed by Eucalyptus saligna. The scoring of defects obeyed the same behavior as total volumetric shrinkage.

In this study, we aimed to analyze the kiln drying quality of Eucalyptus grandis, Eucalyptus saligna and Eucalyptus dunnii woods with respect to volume loss.

\section{MATERIAL AND METHODS}

\subsection{Material selection}

The species Eucalyptus grandis, Eucalyptus saligna and Eucalyptus dunnii were studied. For each species, five trees were felled from an 11-year old stand of clonal material on a plantation belonging to the pulp and paper company Klabin, located in Telêmaco Borba, Paraná state, Brazil.
The trees presented breast high diameter greater than $200 \mathrm{~mm}$, straight trunks and apparently no plant diseases. Only the first logs of each tree were used, corresponding to the first 3,000 mm length, which was further broken down into flatsawn boards of $30 \times 150 \times 3,000 \mathrm{~mm}$. After sawing, the boards were trimmed to $745 \mathrm{~mm}$ length, corresponding to the maximum capacity (in width) of the pilot-scale kiln.

This study was carried out based on information from three other works that studied the same wood: Klitzke and Batista (2010), who analyzed the drying rate and scoring of defects in oven drying small pieces at $100{ }^{\circ} \mathrm{C}$; Batista et al. (2010), who investigated wood density and shrinkage; and Batista (2009), who studied the conventional-temperature kiln drying quality of wood.

Figure 3 presents a cross section of a log showing the position of the flatsawn boards used in this study.

\subsection{Determination of boards volume}

Prior to stacking, we randomly selected $1 / 3$ of each species' boards, which were used for volume loss evaluation. These boards had their volumes determined using a caliper rule (width and

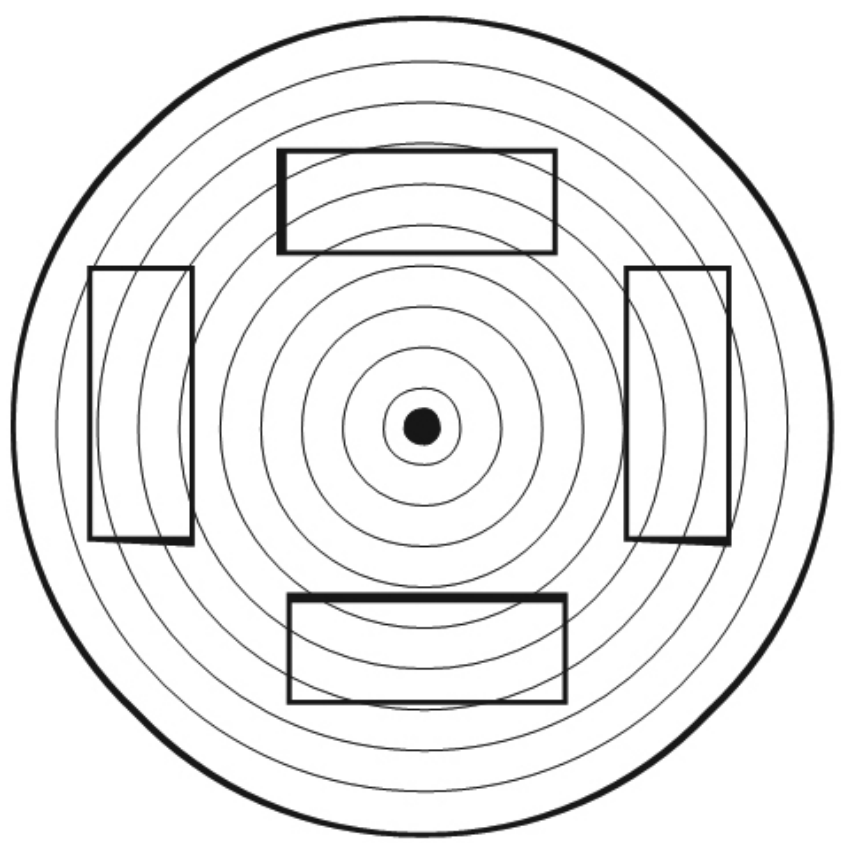

Figure 3. Cross section of a log: position of the flatsawn boards sampled. 
thickness) and a measuring tape (length), as shown in Figure 4. This procedure was repeated for all three kiln batches.

\subsection{Board stacking}

A single stack was used for each kiln batch, measuring $500 \times 745 \times 1,200 \mathrm{~mm}$ in height, width and length, comprising 81 boards ( 27 for each species). The boards of different species were randomly spread in the stack. The stickers used were $25 \mathrm{~mm}$ (square section) and 1,500 $\mathrm{mm}$ long.

\subsection{Kiln and drying schedule}

The wood samples were dried in a pilot-scale $\left(4 \mathrm{~m}^{3}\right)$ conventional-temperature kiln. Heating was performed by electrical resistances and the circulation system was composed of a single propeller-type fan, which blew air at $2 \mathrm{~m} \cdot \mathrm{s}^{-1}$ across the stack, transversally to board length (stack width). Venting and humidification systems comprised two dampers and a steam spray line provided with low pressure steam generated by an electric boiler. Table 1 presents the drying schedule used for the three kiln batches.

The drying conditions were controlled automatically by connection to a personal computer with specific software. Kiln load moisture content was controlled automatically by eight pairs of electric resistive sensors. Four pairs were fixed in two boards of Eucalyptus dunnii (two pairs per board) and the other four pairs were divided among Eucalyptus grandis and Eucalyptus saligna boards.

\subsection{Evaluation of volume loss}

After drying, we evaluated three types of volume losses for each species:

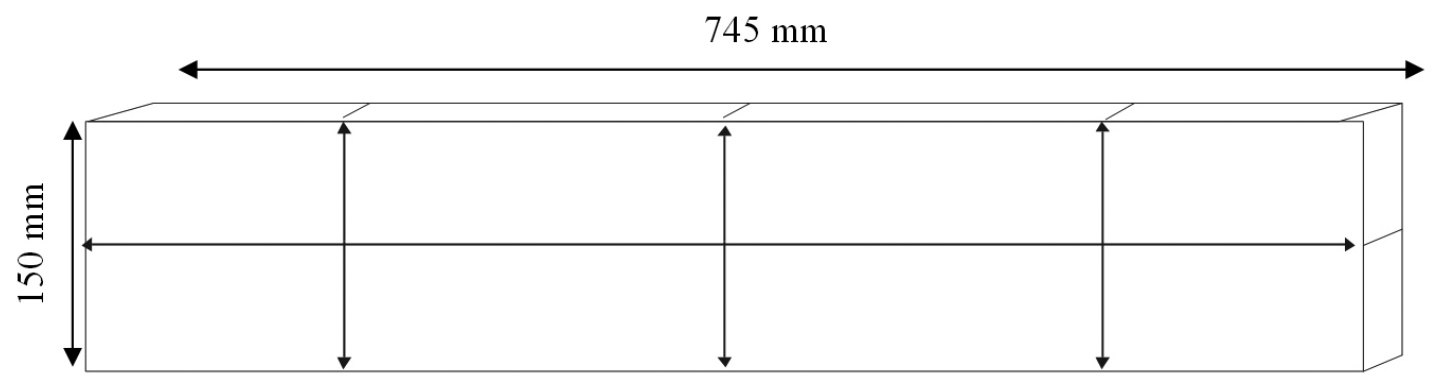

Figure 4. Scheme showing board points of measurement.

Table 1. Drying schedule.

\begin{tabular}{|c|c|c|c|c|c|c|}
\hline \multirow{2}{*}{$\begin{array}{c}\text { Moisture content } \\
\text { of wood }(\%)\end{array}$} & \multicolumn{2}{|c|}{ Temperature $\left({ }^{\circ} \mathrm{C}\right)$} & \multirow{2}{*}{$\begin{array}{c}\text { Relative } \\
\text { humidity (\%) }\end{array}$} & \multirow{2}{*}{$\begin{array}{c}\text { Equilibrium } \\
\text { moisture content }(\%)\end{array}$} & \multirow{2}{*}{$\begin{array}{c}\text { Time } \\
\text { (hours) }\end{array}$} & \multirow{2}{*}{$\begin{array}{l}\text { Drying } \\
\text { gradient }\end{array}$} \\
\hline & Dry bulb & Wet bulb & & & & \\
\hline Warming & 40 & 40 & 100 & - & 3 & - \\
\hline 45 & 40 & 38 & 88 & 18 & - & 2.5 \\
\hline 35 & 44 & 41 & 84 & 16 & - & 2.2 \\
\hline 31 & 46 & 42 & 78 & 14 & - & 2.2 \\
\hline 28 & 50 & 45 & 77 & 14 & - & 2.0 \\
\hline 25 & 54 & 48 & 71 & 12 & - & 2.1 \\
\hline 20 & 58 & 49 & 64 & 10 & - & 2.0 \\
\hline 17 & 60 & 49 & 55 & 8 & - & 2.1 \\
\hline 15 & 62 & 49 & 48 & 7 & - & 2.1 \\
\hline 12 & 66 & 51 & 46 & 6 & - & 2.0 \\
\hline 10 & 66 & 47 & 35 & 5 & - & 2.0 \\
\hline Equalizing-10 & 64 & 56 & 66 & 8 & 8 & - \\
\hline Conditioning-10 & 62 & 56 & 73 & 14 & 8 & - \\
\hline
\end{tabular}


- Shrinkage loss, corresponding to the apparent loss in volume due to the reductions of board dimensions after drying of bound water (Equation )1;

- Machining loss, corresponding to the loss in volume after the boards were machined in order to eliminate cupping, collapse and end cracks (Equation 2);

- Total loss, corresponding to the ratio between the initial (saturated) and final (machined) dimensions of the assessed boards (Equation 3).

$\beta_{v l}=\left[\sum_{i=1}^{N}\left(\frac{V s_{i}-V 10 \%_{i}}{V s_{i}}\right)\right] \times 100$

$\mathrm{M}_{v l}=\left[\sum_{i=1}^{N}\left(\frac{V 10 \%_{i}-V m_{i}}{V 10 \%_{i}}\right)\right] \times 100$

$T_{v l}=\left[\sum_{i=1}^{N}\left(\frac{V s_{i}-V m_{i}}{V s_{i}}\right)\right] \times 100$

where: $\quad \beta_{\mathrm{vl}}=$ shrinkage volume loss (\%); $\mathrm{M}_{\mathrm{vl}}=$ machining volume loss (\%); $\mathrm{T}_{\mathrm{vl}}=$ total volume loss (\%); V10\% $=$ volume at $10 \%$ moisture content of the $\mathrm{i}^{- \text {th }}$ board $\left(\mathrm{m}^{3}\right) ; V s_{\mathrm{i}}=$ initial saturated volume of the $\mathrm{i}^{- \text {th }}$ board $\left(\mathrm{m}^{3}\right) ; V m_{\mathrm{j}}=$ machined volume of the $\mathrm{i}^{-{ }^{\text {th }}}$ board $\left(\mathrm{m}^{3}\right)$.

As the drying conditions were always the same, volume losses could be interpreted as a particular behavior characteristic to each species.

\subsection{Statistical analysis}

Prior to Analysis of Variance (ANOVA), we applied the Bartlett's test, which tests the null hypothesis whether the standard deviations of data for the different volume losses of each treatment are the same. It is one of the most important assumptions underlying ANOVA.

Different volume losses per species were analyzed according to a completely randomized design, with application of one-way ANOVA (95\% confidence level) to evaluate the influence of the species on the volume loss results.

In cases where statistically significant difference between means was observed, Tukey's multiple range test (95\% confidence level) was applied to determine which means were different from each other.

\section{RESULTS AND DISCUSSION}

The mean duration of the three kiln batches was 453 hours, which can be considered a slow drying process, expected for the eucalypt species.

Tables 2, 3 and 4 present the summary statistics of shrinkage, machining and total volume losses per species, respectively.

Table 2. Summary statistics of partial shrinkage per species.

\begin{tabular}{|lcc|}
\multicolumn{1}{c}{ Species } & $\begin{array}{c}\text { Mean partial } \\
\text { shrinkage (\%) }\end{array}$ & $\begin{array}{c}\text { Coefficient of } \\
\text { variation (\%) }\end{array}$ \\
\hline Eucalyptus grandis & $8.4^{\mathrm{a}}$ & 25.0 \\
Eucalyptus saligna & $10.3^{\mathrm{b}}$ & 21.5 \\
Eucalyptus dunnii & $13.0^{\mathrm{c}}$ & 22.8 \\
Bartlett's test & \multicolumn{3}{c}{$1.05^{\mathrm{ns}}$} \\
\hline F-ratio & \multicolumn{2}{c}{$25.28^{* *}$} \\
\hline
\end{tabular}

ns: not statistically significant at the $95 \%$ confidence level; $* *$ : statistically significant at the $99 \%$ confidence level. Means in the same column with a different letter are significantly different $(\mathrm{p}<0.05)$ by the Tukey's multiple range test.

Table 3. Summary statistics of machining volume loss per species.

\begin{tabular}{lcc}
\multicolumn{1}{c}{ Species } & $\begin{array}{c}\text { Mean machining } \\
\text { volume loss (\%) }\end{array}$ & $\begin{array}{c}\text { Coefficient of } \\
\text { variation (\%) }\end{array}$ \\
\hline Eucalyptus grandis & $11.9^{\mathrm{a}}$ & 81.3 \\
Eucalyptus saligna & $10.9^{\mathrm{a}}$ & 80.8 \\
Eucalyptus dunnii & $17.9^{\mathrm{b}}$ & 67.8 \\
Bartlett's test & \multicolumn{3}{c}{$1.03^{\mathrm{ns}}$} \\
F-ratio & \multicolumn{3}{|c}{$4^{*}$} \\
\hline
\end{tabular}

ns: not statistically significant at the $95 \%$ confidence level; ${ }^{*}$ : statistically significant at the $95 \%$ confidence level. Means in the same column with a different letter are significant different $(\mathrm{p}<0.05)$ by the Tuckey's multiple range test.

Table 4. Summary statistics of total volume loss per species.

\begin{tabular}{|lcc|}
\multicolumn{1}{c}{ Species } & $\begin{array}{c}\text { Mean total } \\
\text { volume loss (\%) }\end{array}$ & $\begin{array}{c}\text { Coefficient of } \\
\text { variation (\%) }\end{array}$ \\
\hline Eucalyptus grandis & $19.4^{\mathrm{a}}$ & 41.6 \\
\hline Eucalyptus saligna & $20.1^{\mathrm{a}}$ & 41.3 \\
Eucalyptus dunnii & $28.4^{\mathrm{b}}$ & 40.6 \\
\hline Bartlett's test & \multicolumn{3}{|c|}{$1.06^{\mathrm{ns}}$} \\
\hline F-ratio & \multicolumn{3}{c}{$8.40^{* *}$} \\
\hline
\end{tabular}

ns: not statistically significant at the $95 \%$ confidence level; ${ }^{* *}$ : statistically significant at the $99 \%$ confidence level. Means in the same column with a different letter are significant different $(\mathrm{p}<0.05)$ by the Tuckey's multiple range test. 
According to Bartlett's test statistics, presented in Tables 2, 3 and 4, there was no statistically significant difference between the standard deviations at the 95\% confidence level for any volume loss analyzed; therefore, it was possible to apply ANOVA.

According to the data presented in Table 2, Eucalyptus grandis was the most dimensionally stable species among the three. This result is in agreement with Batista et al. (2010), who studied the same wood as in this study. They assessed the total volumetric shrinkage (from saturated to oven dried) and obtained statistically different means of $14.1 \%$, $15.2 \%$ and $18.7 \%$, respectively for Eucalyptus grandis, Eucalyptus saligna and Eucalyptus dunnii.

Regarding drying defects related to wood shrinkage, Eucalyptus grandis is expected to present fewer defects than the other species, while Eucalyptus dunnii is the most prone to such defects, because it was the most unstable species among then.

Table 3 presents the results of machining volume loss. Cupping and collapse were the most harmful drying defects, regarding wood yield, after machining.

Eucalyptus dunnii species presented the greatest volume loss in machining performed to eliminate cupping and collapse of its boards. There was no statistically significant difference between the means of machining volume loss of Eucalyptus grandis and Eucalyptus saligna.

This result means that shrinkage alone was not responsible for all the machining volume losses, because if so, Eucalyptus grandis would have presented the smallest machining volume loss, which did not happen.

According to literature information, cupping is a drying defect related to shrinkage, but collapse is not (Simpson, 1991; Glass \& Zelinka 2010). This discussion is in agreement with Batista (2009), who evaluated drying defects of the same material as in this study.

Batista (2009) found that among the species studied, Eucalyptus dunnii presented the highest incidence of cupping and collapse, respectively affecting $74.1 \%$ and $55.6 \%$ of the boards. This is why this species presented the highest machining volume loss.

Still according to Batista (2009), Eucalyptus saligna presented the lowest collapse incidence
(28.8\% of the boards versus $35.8 \%$ for Eucalyptus grandis), while Eucalyptus grandis presented the same for cupping (60.5\% of the boards versus $67.9 \%$ for Eucalyptus saligna).

We expected Eucalyptus grandis to present less cupping than Eucalyptus saligna, because it is a more dimensionally stable wood (Table 2), which actually occurred. The same can be said about the collapse behavior of Eucalyptus saligna, because its wood is denser than Eucalyptus grandis (Batista et al., 2010), meaning higher mechanical resistance and smaller incidence of collapse.

Table 4 shows the results of total volume loss, which can be summarized as the sum of the partial and machining volume losses.

According to the data in Tables 3 and 4, total and machining volume losses presented the same tendency, meaning that Eucalyptus dunnii presented the highest mean, followed by Eucalyptus grandis and Eucalyptus saligna, which did not differ statistically from each other. This result for Eucalyptus dunnii was due to a combination of harmful characteristics, such as dimensional instability and low permeability (due to higher density).

Although Eucalyptus dunnii presented the highest mean total volume loss, $28.4 \%$, this result was smaller than the $34.74 \%$ obtained by Klitzke \& Batista (2008), who worked with wood from a 13year old planted forest.

The results of volume loss are in accordance with those by Rocha (2000), who studied the quality of Eucalyptus grandis and Eucalyptus dunnii lumber. The author also concluded that Eucalyptus dunnii lumber presented worse quality than Eucalyptus grandis.

Klitzke \& Batista (2010) studied the scoring of defects in oven drying at $100{ }^{\circ} \mathrm{C}$ of the same material as in this study and found that Eucalyptus dunnii, when kiln dried, would present the worst quality. On the other hand, the authors observed that Eucalyptus grandis would have the best quality, followed by Eucalyptus saligna. The same results were proved in this work, according to the absolute data on total volume loss. Thus, this study helps to support the method of assessing the quality of small pieces of wood dried at $100{ }^{\circ} \mathrm{C}$ and to predict real kiln drying quality. 


\section{CONCLUSIONS}

Eucalyptus grandis was the most dimensionally stable wood and presented the smallest volume loss due to shrinkage.

Although they showed different shrinkage behaviors, Eucalyptus grandis and Eucalyptus saligna presented the same drying quality regarding machining and total volume losses. These species can be considered the same for kiln drying.

Eucalyptus dunnii presented the worst quality after drying. This species should not be kiln dried in the same batch as Eucalyptus grandis and Eucalyptus saligna.

Shrinkage, machining and total volume losses proved to be suitable tools to assess kiln drying quality of wood.

The drying schedule was not adequate and should be improved, because the species presented high levels of boards with drying defects.

\section{SUBMISSION STATUS}

Received: 02/15/2013

Accepted: 05/16/2013

Published: 06/30/2013

\section{CORRESPONDENCE TO}

\section{Djeison Cesar Batista}

Departamento de Ciências Florestais e da Madeira, Universidade Federal do Espírito Santo - UFES, Av. Governador Lindemberg, 316, Centro, CEP 29550-000, Jerônimo Monteiro, ES, Brasil e-mail: djeison.batista@ufes.br

\section{REFERENCES}

Batista DC. Qualidade da secagem convencional conjunta da madeira de nove clones do gênero Eucalyptus [dissertação]. Curitiba: Setor de Ciências Agrárias, Universidade Federal do Paraná; 2009.

Batista DC, Klitzke RJ, Santos CVT. Densidade básica e retratibilidade da madeira de clones de três espécies de Eucalyptus. Ciência Florestal 2010; 20(4): 665-674.

Bergman R. Drying and control of moisture content and dimensional changes. In: Forest Products Laboratory. Wood Handbook: Wood as an engineering material. Madison: United States Department of Agriculture, Forest Service, Forest Products Laboratory; 2010.

Glass SV, Zelinka SL. Moisture relations and physical properties of wood. In: Forest Products Laboratory. Wood Handbook: Wood as an engineering material. Madison: United States Department of Agriculture, Forest Service, Forest Products Laboratory; 2010.

Klitzke RJ, Batista DC. Development of an experimental drying schedule for Eucalyptus dunnii wood aiming further industrial application. In: Proceedings of the $51^{\text {st }}$ International Convention of Society of Wood Science and Technology; 2008; Concepción. Concepción; 2008.

Klitzke RJ, Batista DC. Ensaio de taxa de secagem e escore de defeitos para a predição da qualidade de secagem convencional da madeira de Eucalyptus. Scientia Forestalis 2010; 38(85):97-105.

Langrish T, Walker, J. Drying of timber. In: Walker J, editor. Primary wood processing: principles and practice. Berlin: Springer; 2006. PMCid:1450386. http://dx.doi. org/10.1007/1-4020-4393-7_8

Rocha MP. Eucalyptus grandis Hill ex Maiden e Eucalyptus dunnii Maiden como fontes de matériaprima para serrarias [tese]. Curitiba: Setor de Ciências Agrárias, Universidade Federal do Paraná; 2000.

Simpson WT. Dry Kiln Operator's Manual. Madison: United States Department of Agriculture, Forest Service, Forest Products Laboratory; 1991. 